\title{
Development of a lethal model of peritonitis for assessment of laparoscopic and laparotomic treatments in rats ${ }^{1}$
}

\author{
Desenvolvimento de um modelo letal de peritonite para avaliação do tratamento por \\ laparoscopia e laparotomia em ratos
}

\author{
Wilson Salgado Júnior², José Sebastião dos Santos ${ }^{3}$, Fernando de Queiroz Cunha ${ }^{4}$ \\ 1. Research performed at Gastroenterology Division, Department of Surgery and Anatomy of the Faculty of Medicine of Ribeirão Preto, \\ University of São Paulo (FMRP-USP), Brazil. \\ 2. MD, PhD, Gastroenterology Division, Department of Surgery and Anatomy, FMRP-USP, Brazil. \\ 3. MD, PhD, Full Professor, Gastroenterology Division, Department of Surgery and Anatomy, FMRP-USP, Brazil. \\ 4. MD, PhD, Associate Professor, Department of Pharmacology, FMRP-USP, Brazil.
}

\begin{abstract}
Purpose: Development of a lethal model of peritonitis to assess the results of treating that peritonitis using videolaparoscopy and laparotomy. Methods: We developed a model of peritonitis in rats using cecal ligation (CLP) against a 2-mm diameter rigid mold and puncture. Two experiments were performed: determination of seven-day lethality; and analysis of white cell counts, blood cultures and cytokines (Interleukin-1 beta, Tumor Necrosis Factor-alpha and IL-6). The animals were divided into four groups: I - Sham surgery; II - CLP; III - CLP + Videolaparoscopy; and IV- CLP + Laparotomy . Results: Seven-day lethality was $0 \%$ in group I, $80 \%$ in the group II $(p<0.05), 60 \%$ in group III , and $20 \%$ in group IV. There was a significant reduction in leukocyte counts and higher levels of serum IL-1 beta, TNF-alpha and IL-6 in the group II compared to controls. The percentages of positive blood cultures were higher after videolaparoscopic compared to laparotomic treatment. Conclusion: The experimental model provoked a lethal form of peritonitis and that videolaparoscopic treatment had more bacteraemia than laparotomy.
\end{abstract}

Key words: Peritonitis. Laparotomy. Laparoscopy. Cytokines. Lethality. Rats.

\section{RESUMO}

Objetivo: Desenvolvimento de um modelo letal de peritonite para avaliar o tratamento desta peritonite por videolaparoscopia e laparotomia. Métodos: Foi desenvolvido um modelo de peritonite em ratos utilizando ligadura do ceco (CLP) contra um molde rígido de $2 \mathrm{~mm}$ de diâmetro, seguido de punção do órgão. Dois experimentos foram realizados: determinação da letalidade de 7 dias; e análise da leucometria, hemocultura e dos valores de citocinas (Interleucina-1 beta, TNF-alfa e IL-6). Os animais foram divididos em quatro grupos: I - Cirurgia simulada; II - CLP; III - CLP + Videolaparoscopia; e IV- CLP + Laparotomia . Resultados: A letalidade de sete dias foi de $0 \%$ no grupo I, $80 \%$ no grupo II ( $p<0.05$ ), $60 \%$ no grupo III , e 20 $\%$ no grupo IV. Houve uma redução significativa na contagem de leucócitos e maiores níveis de citocinas séricas no grupo II quando comparado com o grupo controle. A porcentagem de hemoculturas positivas foi maior após videolaparoscopia quando comparado com o tratamento por laparotomia. Conclusão: O modelo experimental provocou uma forma de peritonite letal e que o tratamento por videolaparoscopia apresenta maiores taxas de bacteremia que o tratamento por laparotomia. Descritores: Peritonite. Laparotomia. Laparoscopia. Citocinas. Letalidade. Ratos.

\section{Introduction}

Videolaparoscopy is frequently used for the surgical treatment of abdominal conditions of an inflammatory and infectious nature that have local manifestations ${ }^{1}$. However, the use of videolaparoscopy in the presence of generalized bacterial peritonitis is controversial. Patients submitted to laparoscopic repair of a perforated peptic ulcer presented higher cytokine levels when treated by videolaparoscopy, although the increase was not significant ${ }^{2}$. In an animal model of long-term sepsis obtained by gastric perforation in pigs, a significant increase in the extent and severity of peritonitis and bacteremia was observed after treatment by videolaparoscopy ${ }^{3}$. On the other hand, in another study using a model of peritonitis induced by inoculation of feces into the peritoneal cavity of rats, laparoscopy was not associated with a significant increase in bacteremia ${ }^{4}$. Among the limitations of videolaparoscopic access for the treatment of peritonitis, the most significant is the possibility that high intra-abdominal pressure in the presence of pneumoperitoneum will induce bacterial translocation, along with the attendant bacteremia and death ${ }^{5}$. The aim of the present study was to develop a highly lethal model of diffuse bacterial peritonitis and to assess the results of treatment involving videolaparoscopic and laparotomic access. 


\section{Methods}

In the present study, three experiments were carried out: Experiment 1 -Standardization of the peritonitis model: a total of 103 male Wistar rats weighing 270-330 g were anesthetized with ether and submitted to $1-\mathrm{cm}$ median laparotomy in which the cecum was exteriorized. First, 5 animals were submitted to ligation near the base of the cecum without calibrating the tying of the knot and two punctures were then made in the cecum using an 18-gauge catheter , according to the classical model previously described $^{6}$. Subsequently, 98 rats were operated upon. In these 98 animals, the knot was tied against a rigid 2-mm diameter mold in order to standardize the degree of cecal subocclusion. This was immediately followed by perforation of the cecum with either a 17-gauge or 21-gauge needle (Figure 1).

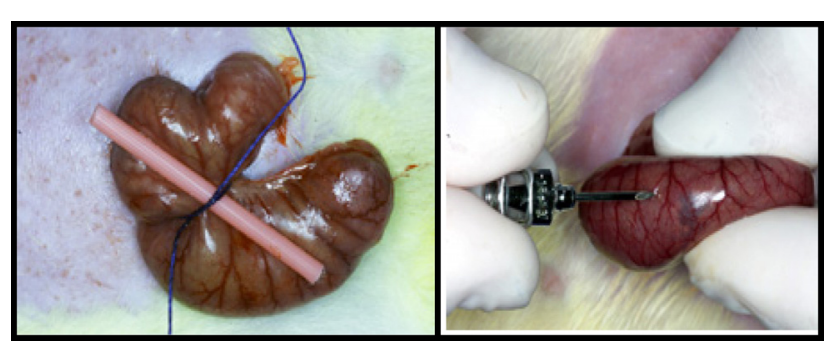

FIGURE 1 - Cecal ligation against a $2 \mathrm{~mm}$ diameter rigid mold, just below the ileo-cecal junction, followed by punctures in the organ with a 17-gauge needle

The number of punctures varied. At the end of this procedure, the ligated and perforated cecum was reintroduced into the abdominal cavity and closure of the abdomem was performed. All animals were assessed in terms of seven-day survival. Experiment 2 - Assessment of lethality: 20 animals were equally divided into four groups: I - Sham surgery (SS); II - Cecum ligation and puncture (CLP); III - CLP + Videolaparoscopy (VLAP); IV - CLP + Laparotomy (LAP). Treatment of peritonitis was performed $6 \mathrm{~h}$ after CLP and consisted of cecectomy + washing the cavity with $400 \mathrm{ml}$ of physiological saline infused at constant flow and pressure. Intra abdominal pressure was mantained at $12 \mathrm{mmHg}$ while VLAP was performed. Seven-day lethality was then assessed. Experiment 3 - Assessment of bacteremia and of the systemic inflammatory response: 36 animals were divided into four equal groups. Right carotid arteries were dissected and catheterized for blood collection and volume replacement, which were performed at $9 \mathrm{~h}$ after CLP or SS. The blood collected from each animal was submitted to microbiological analysis, blood count and ELISA cytokine determination (IL-1, IL-6 and TNF alpha). After 24h, each animal was again anesthetized and submitted to laparotomy. Blood was then collected directly from the inferior vena cava and subjected to same analyses. Immediately thereafter, the animals were sacrificed. Mortality data were analyzed statistically by the Chi-square test, white blood cell data were analyzed by Tukey's test, blood culture data by logistic analysis according to a factorial scheme, and cytokine data by $\mathrm{F}$ test. In all analyses, values of $p<0.05$ were considered significant.

\section{Results}

Step 1 - Induction of peritonitis: The target lethality was obtained with 14 or more punctures of the suboccluded cecum with a 17-gauge needle (Table 1).

TABLE 1 -Assessment of seven-day animal lethality according to needle type and number of punctures

\begin{tabular}{lccc}
\hline Type of needle & $\begin{array}{c}\mathbf{N}^{\mathbf{0}} \text { of } \\
\text { punctures }\end{array}$ & $\begin{array}{c}\mathbf{N}^{\mathbf{0}} \text { of } \\
\text { rats }\end{array}$ & $\begin{array}{c}\text { Lethality } \\
\text { rate } \mathbf{( \% )}\end{array}$ \\
\hline 18-gauge catheter & 2 & 5 & 20 \\
\hline 21-gauge & 5 & 5 & 20 \\
& 10 & 5 & 20 \\
& 15 & 5 & 20 \\
20 & 10 & 50 \\
& 25 & 10 & 50 \\
& 30 & 5 & 40 \\
\hline 17-gauge & 10 & 5 & 80 \\
& 11 & 5 & 80 \\
& 12 & 5 & 80 \\
& 13 & 9 & 66 \\
& 14 & 19 & 89 \\
& 15 & 5 & 80 \\
& 20 & 5 & 100 \\
& 25 & 5 & 80 \\
\hline
\end{tabular}

Step 2 - Assessment of lethality after treatment: The lethality rate was zero in the SS group, as opposed to $80 \%$ in the CLP (untreated peritonitis) group $(\mathrm{p}<0.05)$. Lethality in the VLAP group was also higher than that in the LAP group (60\% and $20 \%$, respectively), although the difference was not statistically significant.

Step 3 -Assessment of bacteremia and of the systemic inflammatory response:

3.1 - White cell counts: Leukocyte numbers were significantly lower in the CLP group than in the SS group (mean values of 4240 and 9500 cells $/ \mathrm{mm}^{3}$, respectively) $(\mathrm{p}<0.01)$. In addition, mean white cell counts in the CLP + VLAP group were comparable to those in the untreated CLP group ( 4440 cells $/ \mathrm{mm}^{3}$ ) and leukopenia persisted at 24 $\mathrm{h}\left(4280\right.$ cells $\left./ \mathrm{mm}^{3}\right)$. In contrast, the mean number of leukocytes in the CLP + LAP group tended to increase after 9 hours $\left(5360\right.$ cells $\left./ \mathrm{mm}^{3}\right)$ and the leukopenia disappeared after $24 \mathrm{~h}$ (mean, 6420 cells $/ \mathrm{mm}^{3}$ ).

3.2 - Blood microbiology: The percentage of positive blood cultures 9 hours after the beginning of the experiment was significantly greater in the CLP (untreated peritonitis) group than in the control group ( $80 \%$ and $0 \%$, respectively) $(p<0.01)$. In the CLP + VLAP group, the rate of positive blood cultures was significantly higher than in the CLP + LAP group both at $9 \mathrm{~h}(100 \%$ vs. $66 \%)(\mathrm{p}<0.01)$ and $24 \mathrm{~h}$ $(88 \%$ vs. $33 \%)(p<0.01)$. (Figure 2$)$

3.3 - Cytokine determination: Compared to animals in the SS group (controls), those in the CLP group presented higher levels of all cytokines tested at $9 \mathrm{~h}$ and $24 \mathrm{~h}$ after treatment $(\mathrm{p}<0.01)$. No significant difference in cytokine levels was observed between the CLP + VLAP group and the CLP + LAP group. (Table 2) 


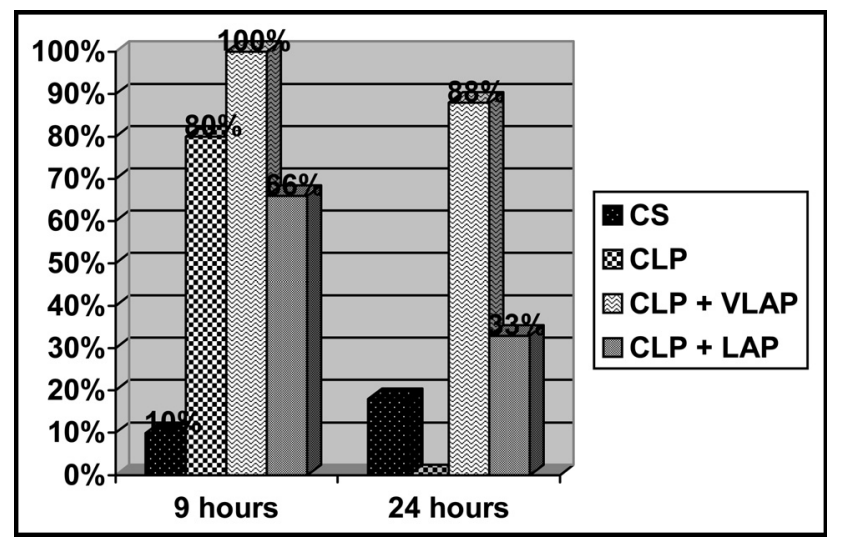

FIGURE 2 - Percentage of positive blood cultures of the 4 groups. Nine hours after the beginning of the experiment, the percentage was significantly greater in the CLP (untreated peritonitis) group than in the Sham surgery group $(\mathrm{p}<0.01)$. In the CLP + VLAP group, the rate of positive blood cultures was significantly higher than in the CLP + LAP group both at $9 \mathrm{~h}(\mathrm{p}<0.01)$ and $24 \mathrm{~h}(\mathrm{p}<0.01)$

TABLE 2 - Mean (+ SD) values of cytokines determined at $9 \mathrm{~h}$ and $24 \mathrm{~h}$

\begin{tabular}{llllll}
\hline Cytokines & Time & \multicolumn{5}{c}{ Groups } \\
\cline { 3 - 6 } & & SS & CLP & CLP+ VLAP & CLP + LAP \\
\hline IL-1 & $9 \mathrm{~h}$ & $256.7 \pm 263,5$ & $662.7 \pm 319.6$ & $734.8 \pm 482.5$ & $633 \pm 310.2$ \\
$(\mathrm{pg} / \mathrm{ml})$ & $24 \mathrm{~h}$ & $206.1 \pm 198.2$ & $252.5 \pm 194.7$ & $859.6 \pm 821.7$ & $455.1 \pm 194$ \\
$\mathrm{IL}-6$ & $9 \mathrm{~h}$ & $247.5 \pm 233.1$ & $1911.2 \pm 1155.5$ & $1593.2 \pm 823.2$ & $1486.8 \pm 512.1$ \\
$(\mathrm{pg} / \mathrm{ml})$ & $24 \mathrm{~h}$ & $84.8 \pm 67.6$ & $781.1 \pm 655.8$ & $709.4 \pm 378.9$ & $500.4 \pm 522.9$ \\
$\mathrm{TNF}$ & $9 \mathrm{~h}$ & $44.6 \pm 65.3$ & $158 \pm 266.4$ & $290.2 \pm 440.4$ & $126.7 \pm 113.9$ \\
$(\mathrm{pg} / \mathrm{ml})$ & $24 \mathrm{~h}$ & 0 & $12.6 \pm 10$ & $121.8 \pm 157$ & $241.4 \pm 627.4$ \\
\hline
\end{tabular}

\section{Discussion}

Videolaparoscopic access for the treatment of abdominal conditions with localized infection has been increasingly recommended. However, its use in the presence of generalized peritonitis remains controversial, thereby justifying further investigation. The technique of inducing bacterial peritonitis by cecal ligation and puncture creates a useful experimental model of the disease. However, failure to standardize the degree of cecal subocclusion may lead to ischemic and necrotic effects, complicating the infectious process and producing unpredictable lethality rates. The methods employed in this study (calibrated cecal subocclusion followed by puncture with a 17-gauge needle) created a model of bacterial peritonitis that led to bacteremia, leukopenia, increased cytokine levels, and high lethality. These complications have also been observed in longterm peritonitis in humans ${ }^{7}$. In the present study, videolaparoscopic treatment resulted in a greater percentage of positive blood cultures $(p<0.01)$ than did laparotomic treatment. In addition, leukopenia in the VLAP group tended to persist and was accompanied by elevated cytokine levels and lethality rates. These indirect findings suggest that VLAP treatment induces bacterial translocation. The methods for the mechanical removal of peritoneal fluid should also be considered in the interpretation of the results. The limitations of videolaparoscopy in removing the debris and the fluid volume used for lavage of the peritoneal cavity may influence the course of the infectious-inflammatory process. In a model of bacterial peritonitis in rats submitted to feces inoculation into the peritoneal cavity, the animals treated by laparoscopy presented only slightly higher TNF alpha values 1 hour after surgery than the group treated by laparotomy, with this difference being no longer observed 2 days after surgery. However, the authors used a non-lethal model of peritonitis and, importantly, a pneumoperitoneum of only $8 \mathrm{mmHg}$, much lower than that reported in other studies. ${ }^{8}$ In the present study, we did not observe differences between the two surgical routes regarding TNF alpha, IL-6 and IL-1, as reported by others. ${ }^{9}$ Thus, we may conclude that the aggression caused by peritonitis and by bacteremia greatly exceeded the stimulus of the surgical trauma in terms of cytokine release. 


\section{Conclusion}

The experimental model provoked a lethal form of peritonitis and that videolaparoscopic treatment had more bacteraemia than laparotomy.

\section{References}

1. Attwood SEA, Hill ADK, Murphy PG, Thornton J, Stephens RB. A prospective randomized trial of laparoscopic versus open appendectomy. Surgery. 1992;112:497-501.

2. Lau YW, Lo SY, Ng EKW, Lee DWH, Lam YH, Chung SCS. A randomized comparison of acute phase response and endotoxemia in patients with perforated peptic ulcers receiving laparoscopic or open patch repair. Am J Surg. 1998;175:325-7.

3. Bloechle C, Emmermann A, Strate T, Scheurlen UJ, Schneider C, Achilles E, Wolf M, Mack D, Zornig C, Broelsch CE. Laparoscopic vs. open repair of gastric perforation and abdominal lavage of associated peritonitis in pigs. Surg Endosc. 1997;12:212-8.
4. Jacobi CA, Ordemann J, Böhm B, Zieren HU, Volk HD, Lorenz W, Halle E, Müller JM. Does laparoscopy increase bacteremia and endotoxemia in a peritonitis model? Surg Endosc. 1997;11:235-8.

5. Silibary T, Wissig SL. Lymphatic absorption from the peritoneal cavity. Regulation of patency of mesothelial stomata. Microvasc Res. 1983;25:22-39.

6. Wichterman KA, Chaudry IH, Baue AE. Studies of peripheral glucose uptake during sepsis. Arch Surg. 1979;114:740-50.

7. Riché FC, Chooley BP, Panis YH. Inflammatory cytokine response in patients with septic shock secondary to generalised peritonitis. Crit Care Med. 2000;28:433-7.

8. Jacobi CA, Ordemann J, Zieren HU, Volk HD, Bauhofer A, Halle E, Müller JM. Increased systemic inflammation after laparotomy vs laparoscopy in an animal model of peritonitis. Arch Surg. 1998;133:258-62.

9. Lau YW, Lo SY, Ng EKW, Lee DWH, Lam YH, Chung SCS. A randomized comparison of acute phase response and endotoxemia in patients with perforated peptic ulcers receiving laparoscopic or open patch repair. Am J Surg. 1998;175:325-7.

\section{Correspondence:}

Wilson Salgado Júnior

Department of Surgery and Anatomy

Hospital das Clínicas - Campus Universitário

14048-900 - Ribeirão Preto - SP - Brazil

e-mail: vpsalgado@netsite.com.br
Conflict of interest: none Financial source: none

Received: August 11, 2006

Review: September 19, 2006

Accepted: October 23, 2006

\section{How to cite this article:}

Salgado Jr W, Santos JS, Cunha FQ. Development of a lethal model of peritonitis for assessment of laparoscopic and laparotomic treatments in rats. Acta Cir Bras. [serial on the Internet] 2007 Jan-Feb;22(1). Available from URL: http://www.scielo.br/acb. 